\title{
Effects of Salt Water Drip Irrigation on Jujube Roots Soil Available Nitrogen Distribution: A Security Assurance Perspective
}

\author{
Xingpeng Wang ${ }^{1}$, Tiecheng Bai ${ }^{2}$, Jinhu Zhi ${ }^{2, *}$ and Zhaoyang $\mathrm{Li}^{2}$ \\ ${ }^{1}$ Farmland Irrigation Research Institute of CAAS,Xinxiang,Henan,453000, China \\ ${ }^{2}$ Tarim University,Alaer,Xinjiang, 843300,China
}

\begin{abstract}
Field experiment was used in this research to study influences brought by salt water with different degrees of mineralization to distribution characteristics of soil available nitrogen and nitrate nitrogen in red jujube root zones when the salt water drip irrigation was carried out to jujubes. It is shown in the results that the distribution content of soil available nitrogen in jujube tree root zones tended to gradually decrease from top to bottom in the soil profile at different growth stages. The soil available nitrogen contents at different growth stages exceeded initial values. The mineralization degrees of salt water which influenced the available nitrogen were successively $3 \mathrm{~g} / \mathrm{L}>4 \mathrm{~g} / \mathrm{L}>2 \mathrm{~g} / \mathrm{L}>C K$, wherein the salt water with mineralization degree of $3 g / L$ brought largest influences to transformation and utilization of available nitrogen in jujube tree root zones; with regard to different growth stages, the available nitrogen content was high in the soil layer with depth of $0-20 \mathrm{~cm}$ in the jujube root zone, and the content was small in the soil layer with depth o 30-50 cm; during drip irrigation with the mineralization degree of over $3 g / L$, the nitrate nitrogen content in soil layers of the jujube tree root zone exceeded the content under fresh water irrigation treatment as a whole.
\end{abstract}

Keywords: Salt water; security technology; drip irrigation; available nitrogen; nitrate nitrogen; red jujube

\section{Introduction}

Soil available nitrogen is the main source of various soil nutrient elements, especially nitrogen. This part of nitrogen can be easily absorbed by plants, mainly exists in the form of ammonium nitrogen, nitrate nitrogen, amino acid, acid amides and easily-decomposed proteins, and plays a very important role in plant growth. The content of soil available nitrogen is influenced by many factors, and shows an obvious superficial clustering phenomenon [1]. Content and distribution of available nitrogen in profiles of farmland soil of different latitudes would change along with changes in soil organic matters and nitrogen level [2]. Population number of soil microbes also has a significant positive correlation with available nitrogen [3]. Of course, application of chemical phosphate fertilizer can also promote increase of available nitrogen content in soil through interionic interactions [4].

At present, researchers' researches about transport of available nitrogen and nitrate nitrogen in soil have mainly concluded that the transport is related with crop absorption. Bai et al. (2006) researched seasonal changing characteristics of available nitrogen content in soil of swamp closed-type wet lands and open-type wet lands[5]. Liu et al. (2008) researched the relations between jujube garden soil available nitrogen and plant absorption dynamics[6]. Feng (1998) and Xing (2008) researched component influences brought by drip irrigation conditions to soil nitrogen of field crops such as cotton and corn as well as transport 
characteristics of nitrogen. Researches about nitrate nitrogen transport always synchronically explore available nitrogen changes and irrigation measures[7-8]. However, as we all know, nitrate is an anion which can hardly be adsorbed by soil colloid, wherein its transport speed and accumulation amount in soil will show obvious changes along with changes in irrigated water amount and water quality. Researches of this type focused on sewage irrigation at the earlier stage[9]. Hayes (1990) found through the research that nitrate nitrogen content in soil irrigated by sewage was obviously higher than that of the soil irrigated by clean water[10]. There are very few researches about changes brought by salt water irrigation to soil nitrogen content, wherein the earliest findings can be traced back to 1990s. Smith (1993) carried out the research of alfalfa with white flower based on slightly-salt water irrigation and found that the annual biologic nitrogen content in soil decreased by $24 \%-47 \%$ in comparison with areas with fresh water irrigation[11]. Li (2009) and Li (2010) et al. analyzed vertical and horizontal distribution characteristics of soil available nitrogen and nitrate nitrogen after salt water irrigation and concluded that recycled water could increase accumulation of soil nitrate nitrogen in soil surface layer and promote crops' absorption of available nitrogen[11-12].

The paper researches influences brought by salt water irrigation with different mineralization degrees to distribution characteristics of available nitrogen and nitrate nitrogen in red jujube root zone soil in order to explore the influencing mechanism of salt water drip irrigation for nitrogen content changes and transport rules in soil and provide a theoretical basis for safe application of salt water irrigation in extremely dry desert zones.

\section{Material and Method}

\subsection{Field Experiment}

The experiment was conducted in Alaer city of Xinjiang province. Zone of the experiment base was 2ha. Belongs to extreme arid desert climate, the lack of annual rainfall (46.7-61.2 $\mathrm{mm})$, the great of annual evaporation (1877.5-2337.4 mm), drought index is7-20. Soil texture is arenaceous soil, soil bulk density is $1.34 \mathrm{~g} \bullet \mathrm{cm} 3$, Field Capacity is $25 \%$, groundwater depth is $3 \mathrm{~m}$.

\subsection{Experiment Materials}

An experiment material is jujube by the agricultural companies of Alar City. High density planting dwarf was used with jujube average height of 1-1.5 $\mathrm{m}$, test zone size of $18 \mathrm{~m} \times 15 \mathrm{~m}$, and spacing of $1 \mathrm{~m} \times 1.5 \mathrm{~m}$.

\subsection{Experiment Design}

We selected inlay-style drip irrigation tube and single linear arrangement laid way, wherein two emitters were set for each tree, and the emitter was installed on site. Dripping from the jujube tree distance is $20 \mathrm{~cm}$, the largest single emitter flow rate $2.4 \mathrm{~L} \cdot \mathrm{h}-1$, working pressure is $0.1 \mathrm{Mpa}$. The treatments consisted of three salinity levels $(2,3$ and $4 \mathrm{~g} \cdot \mathrm{L}-1$, compare with fresh water for the control treatment (salinity $<1 \mathrm{~g} \cdot \mathrm{L}-1$ ), irrigation cycle $7 \mathrm{~d}$, irrigation quota $200 \mathrm{~m} 3 \bullet \mathrm{hm}-2$, all treatments were replicated three times. Salt water main ingredients are $\mathrm{NaCl}$.

To make each treatment of fertilization consistent, the local chicken manure was used as the organic fertilizer and applied for one time at early growth stage of jujube tree roots[13], wherein the amount was $1200 \mathrm{~kg} \bullet 666.7 \mathrm{~m}-2$. Inorganic fertilizers including urea, diammonium phosphate and potassium chloride were used, and they were applied for one 
time at each growth stage[14-15], wherein $40 \%$ of basal urea nitrogen and $60 \%$ of it with water droplets were applied according to the amount of $70 \mathrm{~kg} / 666.7 \mathrm{~m} 2$; all the triple superphosphate fertilizer was applied as base fertilizer and applied according to the amount of $40 \mathrm{~kg} \cdot 666.7 \mathrm{~m}-2$; potassium sulfate $50 \%$ was used as basal, and $50 \%$ of facilities with water droplets was applied according to the amount of $60 \mathrm{~kg} \bullet 666.7 \mathrm{~m}-2$.

\subsection{Sampling and analytical methods}

Drip irrigation with fertilizer on red jujube each growth stage, after irrigation 48 hours measured soil available nitrogen and nitrate nitrogen content. Soil sample collection time was on May 17, May 28, June 28, July 28 and August 28 in years 2013 and 2014 respectively, dates of birth correspond to the early stage of germination, post-germination, flowering, fruiting, and maturity. Table 1 listed the initial value of soil available nitrogen and nitrate nitrogen soil samples were collected from the holes at depths of 10,20,30,40 and 50cm.

Measured using conventional methods of soil nutrients[21], in which soil nitrate nitrogen using the phenol disulphonic acid colorimetry; soil available nitrogen diffusion method using alkali solution. All data analysis and figure were performed using the Excel 2007 software.

\section{Table 1.The initial Value of Soil Available Nitrogen and Nitrate Nitrogen}

\begin{tabular}{|c|c|c|c|c|c|}
\hline Depth $(\mathrm{cm})$ & 10 & 20 & 30 & 40 & 50 \\
\hline Nitrate nitrogen $\left(\mathrm{mg} \cdot \mathrm{kg}^{-1}\right)$ & 30.359 & 28.44 & 19.825 & 18.413 & 20.308 \\
\hline Available nitrogen $\left(\mathrm{mg} \cdot \mathrm{kg}^{-1}\right)$ & 60.46 & 57.52 & 42.11 & 42.03 & 38.29 \\
\hline
\end{tabular}

\section{Empirical Analysis}

Salt water drip's effect on the distribution of soil available nitrogen variability of soil available nitrogen's contents Soil available nitrogen statistical characteristic values of salt water with different salinity under drip irrigation jujube tree root zone were shown in Table 2. The soil available nitrogen content after treatment of different irrigation water salinity was alter drip irrigation treatment were treated with greater differences in the magnitude of changes. The main reason was that the application of nitrogen fertilizer in the soil not only increased the root zone jujube nitrogen content; at the same time saline water also inhibitd date root system cells' absorption of nitrogen. But the judgment for the nitrogen content in soil could not explain the real conditions of different degree of mineralization of soil nitrogen caused by saltwater changes. Thus, by introducing the coefficient of variation (CV) to describe the changes in soil nitrogen characteristics, a comprehensive reflection of the variables (different salinity) which caused jujube root nitrogen changes in soil differences was made.

coefficient of variation (CV)value in the coefficient of variation showed that after freshwater treatment, jujube tree root zone soil nitrogen coefficient variation was the smallest, which indicates the date tree roots on soil nitrogen absorption was relatively stable. After 2 $\mathrm{g} \bullet \mathrm{L}-1,3 \mathrm{~g} \bullet \mathrm{L}-1$ drip irrigation treatment, jujube tree root zone soil nitrogen coefficient of variation was relatively larger, which showed that as water salinity increases, the jujube tree roots stand greater salt stress and the process that soil nitrogen transferred into other nitrogen forms was relatively unstable. However, after $4 \mathrm{~g} \cdot \mathrm{L}-1$ water drip treatment, jujube tree root zone soil nitrogen' CV had appeared to be decreasing. Therefore, it is necessary to research whether saline water salinity exceeding the threshold with the increase in salinity would 
enhance the ability of soil nitrogen fixation, which would thus reduce the losses of soil nitrogen and block the effective utilization of nitrogen in jujube roots as well as determination of the threshold value.

Table 2.Statistic Characteristic of Soil Available Nitrogen

\begin{tabular}{|c|c|c|c|c|c|}
\hline Salinity $\left(\mathrm{g} \cdot \mathrm{L}^{-1}\right)$ & $\begin{array}{c}\text { Range of } \\
\text { measurement } \\
\mathrm{mg} \cdot \mathrm{kg}^{-1}\end{array}$ & $\begin{array}{c}\text { Average } \\
\mathrm{mg} \cdot \mathrm{kg}^{-1}\end{array}$ & $\begin{array}{c}\text { Deviation } \\
\mathrm{mg} \cdot \mathrm{kg}^{-1}\end{array}$ & $\begin{array}{c}\text { Standard } \\
\text { deviation } \\
\left(\mathrm{mg} \cdot \mathrm{kg}^{-1}\right)^{2}\end{array}$ & $\begin{array}{c}\text { Variation } \\
\text { coefficient }(\%)\end{array}$ \\
\hline Freshwater $(<1)$ & $35.65-64.4$ & 48.56 & 86.16 & 9.28 & 19.11 \\
\hline 2 & $27.8-77.15$ & 56.24 & 246.18 & 15.69 & 27.90 \\
\hline 3 & $45.25-126.75$ & 74.86 & 436.53 & 20.89 & 27.91 \\
\hline 4 & $39.25-101.3$ & 67.615 & 307.33 & 17.53 & 25.93 \\
\hline
\end{tabular}

\subsection{The Vertical Distribution of the Soil Available Nitrogen}

Figure 1 were respectively for the root zone soil available nitrogen vertical distribution characteristics of different growth stages under the salinity $2 \mathrm{~g} \cdot \mathrm{L}^{-1}, 3 \mathrm{~g} \cdot \mathrm{L}^{-1}$ and $4 \mathrm{~g} \cdot \mathrm{L}^{-1}$ salt and fresh water control treatment conditions. Seeing from the figures, the control treatment of freshwater at different growth stages of dates root zone soil available nitrogen was gradually decreasing with the increase of soil depth: the highest values of soil available nitrogen content appeared in the depths of $10 \mathrm{~cm}$ and $20 \mathrm{~cm}$; the second content appeared in the depth of 40 $\mathrm{cm}$, and the minimum content appeared in the depths of $30 \mathrm{~cm}$ and $50 \mathrm{~cm}$. At the germination, flowering, fruiting period,soil available nitrogen's average values on the vertical profiles of the mean respectively increased by $2.94 \mathrm{mg}, 1.16 \mathrm{mg}, 1.44 \mathrm{mg}$. In the maturity period, soil available nitrogen as a whole was lower than the initial value which was lower than the initial mean $3.62 \mathrm{mg}$. At different salinity saltwater dripping conditions, soil nitrogen at different growth stages was gradually decreasing from top to bottom: the variation of the soil available nitrogen content along with the depth of soil was in succession $10 \mathrm{~cm}>20 \mathrm{~cm}>30 \mathrm{~cm}>40 \mathrm{~cm}>$ $50 \mathrm{~cm}$. And in vertical profiles at different growth stages on the dates the soil nitrogen as a whole were higher than initial value. Among all the values, available nitrogen values of dates in germination, flowering, fruiting and maturity with $2 \mathrm{~g} \cdot \mathrm{L}^{-1}$ water treatment (Figure 1a) were higher than the initial average mean which had increased by $5.97 \mathrm{mg}, 8.25 \mathrm{mg}, 5.51 \mathrm{mg}$ and $12.92 \mathrm{mg}$, while with $3 \mathrm{~g} \cdot \mathrm{L}^{-1}$ water treatment (Figure $1 \mathrm{~b}$ ) the available nitrogen values had respectively increased by $13.62 \mathrm{mg}, 19.02 \mathrm{mg}, 30.11 \mathrm{mg}$, and $44.37 \mathrm{mg}$. And with $4 \mathrm{~g} \cdot \mathrm{L}^{-1}$ water treatment (Figure 1c) the available nitrogen values were respectively increased by 6.61 $\mathrm{mg}, 13.17 \mathrm{mg}, 20.18 \mathrm{mg}$, and $38.18 \mathrm{mg}$. Through the above analysis, soil available nitrogen affected by the order of the saline water salinity was $3 \mathrm{~g} \cdot \mathrm{L}^{-1}>4 \mathrm{~g} \cdot \mathrm{L}^{-1}>2 \mathrm{~g} \cdot \mathrm{L}^{-1}>$ freshwater. 


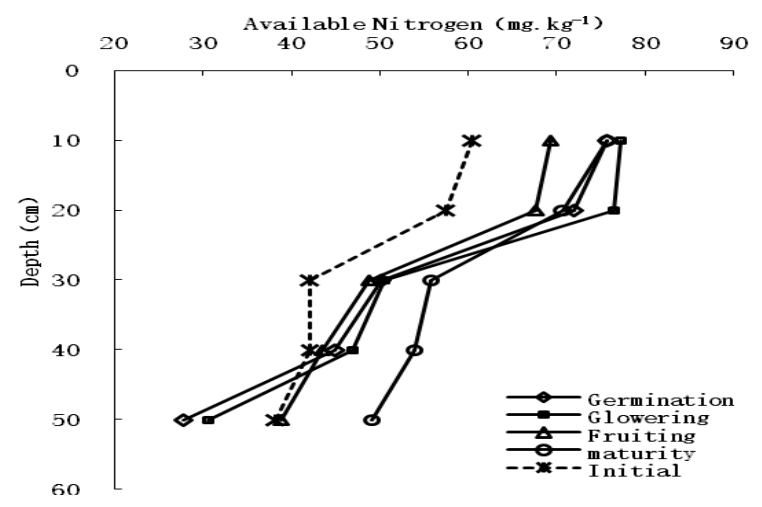

Figure 1(a). Soil Available Nitrogen Vertical Variation:2gL-1 Salt Water

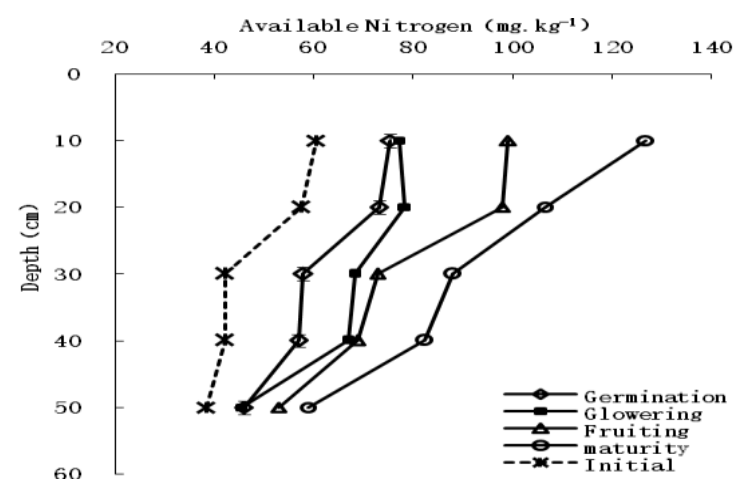

Figure 1(b). Soil Available Nitrogen Vertical Variation:3gL-1 Salt Water

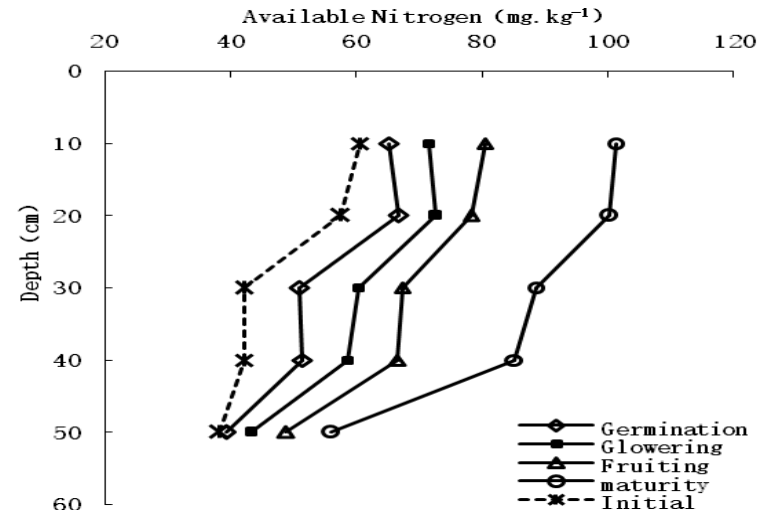

Figure 1(c). Soil Available Nitrogen Vertical Variation:4gL-1 Salt Water 


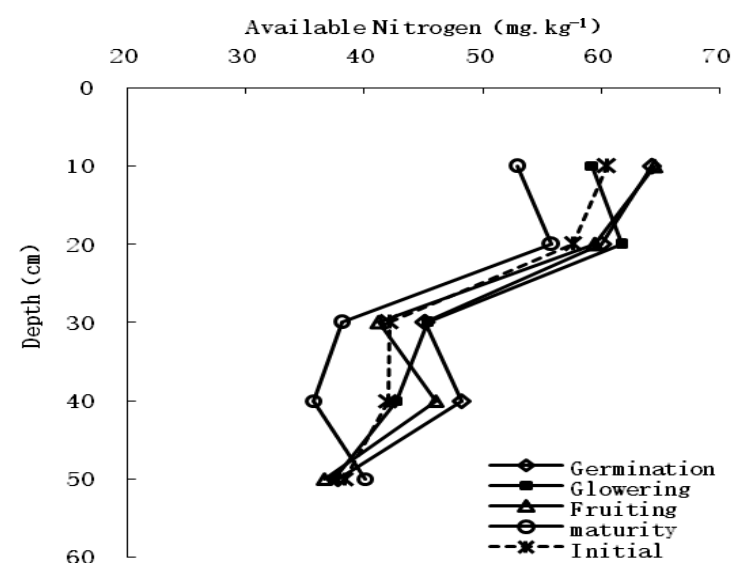

Figure 1(d). Soil Available Nitrogen Vertical Variation: Fresh Water

\subsection{Salt water Drip's Effect on the Distribution of Soil Nitrate Nitrogen}

Variability of soil nitrate nitrogen's contents soil nitrate nitrogen statistical characteristic values of Salt water with different salinity under drip irrigation jujube tree root zone were shown in Table 3. The soil nitrate nitrogen contents of different irrigation water salinity were generally at $5.809-87.32 \mathrm{mg} \cdot \mathrm{kg}^{-1}$. Changes in soil nitrate nitrogen with different treatments were great, which indicated that after water drip irrigation treatment, the jujube tree roots suffered great salt stress and it was difficult to make full use of soil nitrate. CV value in the coefficient of variation showed that after water control and $3 \mathrm{gL}^{-1}$ water treatment, jujube tree root zone soil nitrate coefficient variation was relatively smaller and the content of nitrate in the soil changed not too much, which indicated the date tree roots' absorption of soil nitrates was relatively stable. However, coefficient variation of nitrate drip processing with $2 \mathrm{~g} \cdot \mathrm{L}^{-1}, 4$ $\mathrm{gL}^{-1}$ soil freshwater was relatively larger which meaned nitrate content in the soil changes in a big margin, indicating the date tree roots' absorption of soil nitrate was relative unstable.

Table 3.Statistic Characteristic of Soil Nitrate Nitrogen

\begin{tabular}{|c|c|c|c|c|c|}
\hline salinity $\left(\mathrm{g} \cdot \mathrm{L}^{-1}\right)$ & $\begin{array}{c}\text { range of } \\
\text { measurement } \mathrm{mg} \\
\cdot \mathrm{kg}^{-1}\end{array}$ & $\begin{array}{c}\text { average } \\
\mathrm{mg} \cdot \mathrm{kg} \\
1\end{array}$ & $\begin{array}{c}\text { deviation } \\
\mathrm{mg} \cdot \mathrm{kg}^{-1}\end{array}$ & $\begin{array}{c}\text { standard } \\
\text { deviation } \\
\left(\mathrm{mg} \cdot \mathrm{kg}^{-1}\right)^{2}\end{array}$ & $\begin{array}{c}\text { variation } \\
\text { coefficient }(\%)\end{array}$ \\
\hline freshwater $(<1)$ & $22.049-52.325$ & 38.191 & 100.056 & 10.00 & 26.2 \\
\hline 2 & $5.809-54.028$ & 32.41 & 224.83 & 14.994 & 46.30 \\
\hline 3 & $28.819-87.32$ & 60.787 & 246.52 & 15.7 & 25.83 \\
\hline 4 & $17.613-72.534$ & 41.137 & 264.683 & 16.23 & 39.55 \\
\hline
\end{tabular}

\subsection{The vertical distribution of the soil nitrate nitrogen}

Figure 2 respectively salinity $2 \mathrm{~g} \cdot \mathrm{L}^{-1}, 3 \mathrm{~g} \cdot \mathrm{L}^{-1}, 4 \mathrm{~g} \cdot \mathrm{L}^{-1}$ salt and fresh water control treatment conditions, different growth stages of Jujube of the vertical root distribution characteristics of soil nitrate nitrogen. Could be seen from the figure, the control treatment of water at different growth stages of Jujube, soil nitrate nitrogen increased with soil depth trend was gradually reduced, but the whole was greater than the initial value, at the germination, flowering, fruiting and maturity stages, the mean content of nitrate nitrogen in vertical profiles 
respectively increased by $24.765 \mathrm{mg}, 19.321 \mathrm{mg}, 6.62 \mathrm{mg}$ and $8.185 \mathrm{mg}$ in comparison with initial values on the average. Under the $2 \mathrm{~g} \cdot \mathrm{L}^{-1}$ water treatment (Figure $2 \mathrm{a}$ ), the maximum soil nitrate content appeared in depths of $10 \mathrm{~cm}$ and $20 \mathrm{~cm}$, the minimum value appeared in the depth of $30 \mathrm{~cm}$, and slightly increased in depths of $40 \mathrm{~cm}$ and $50 \mathrm{~cm}$. At fruiting and maturity period, soil nitrate nitrogen levels in depths of $30 \mathrm{~cm}$ and $40 \mathrm{~cm}$ were less than the initial value, the change in the vertical undulating profile, indicating that nitrate nitrogen content in soil instability. At the germination, flowering, fruiting and maturity period, the mean vertical profiles of nitrate nitrogen, respectively, on the average than the initial increase $14.769 \mathrm{mg}$, $13.659 \mathrm{mg}, 5.988 \mathrm{mg}$ and $1.328 \mathrm{mg} .3 \mathrm{~g} \cdot \mathrm{L}^{-1}$ water treatment(Figure $2 \mathrm{~b}$ ), at different growth stages of Jujube, soil nitrate nitrogen were gradually decreasing trend from top to bottom, the depth of the soil as soil nitrate nitrogen of the order was $10 \mathrm{~cm}>20 \mathrm{~cm}>30 \mathrm{~cm}>40 \mathrm{~cm}>50$ $\mathrm{cm}$, and in the overall vertical profile of soil nitrate nitrogen were higher than the initial value. At the germination, flowering, fruiting and maturity period, soil nitrate nitrogen respectively compared with the initial value increase $28.912 \mathrm{mg}, 35.39 \mathrm{mg}, 40.143 \mathrm{mg}$ and $44.828 \mathrm{mg} .4 \mathrm{~g}$ $\cdot \mathrm{L}^{-1}$ water treatment (Figure $2 \mathrm{c}$ ), at different growth stages of Jujube $10 \mathrm{~cm}$ and $20 \mathrm{~cm}$ soil nitrate nitrogen content, in $30 \mathrm{~cm}$ and $40 \mathrm{~cm}$ at the minimum value, and appeared in at $50 \mathrm{~cm}$ slightly increased, but on the vertical profile Soil nitrate nitrogen was higher than the initial value of the whole. At the germination, flowering, fruiting and maturity period, soil nitrate nitrogen, respectively, compared with the initial value increase $13.866 \mathrm{mg}, 16.581 \mathrm{mg}, 12.872$ $\mathrm{mg}$ and $27.353 \mathrm{mg}$. Through the above analysis showed that, at the different growth stages of Jujube , soil nitrate nitrogen affected by the order of the saline water salinity was $3 \mathrm{~g} \cdot \mathrm{L}^{-1}>4 \mathrm{~g}$ $\cdot \mathrm{L}^{-1}>$ Freshwater $>2 \mathrm{~g} \cdot \mathrm{L}^{-1}$.

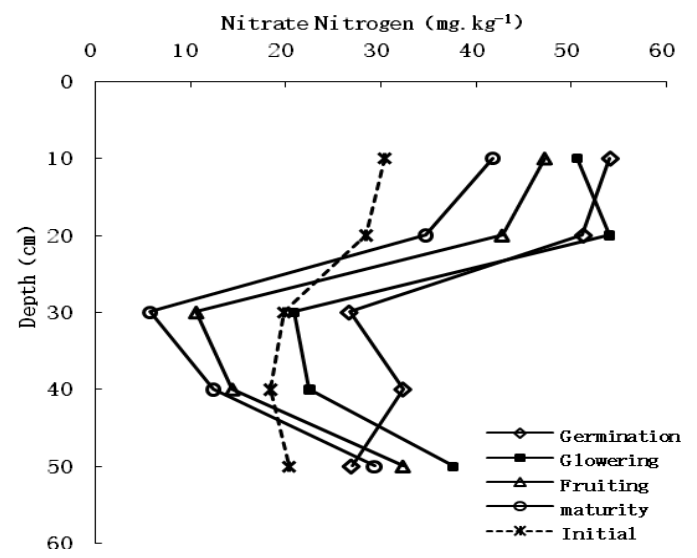

Figure 2 (a). Soil Nitrate Nitrogen Vertical Variation:2gL-1 Salt Water 


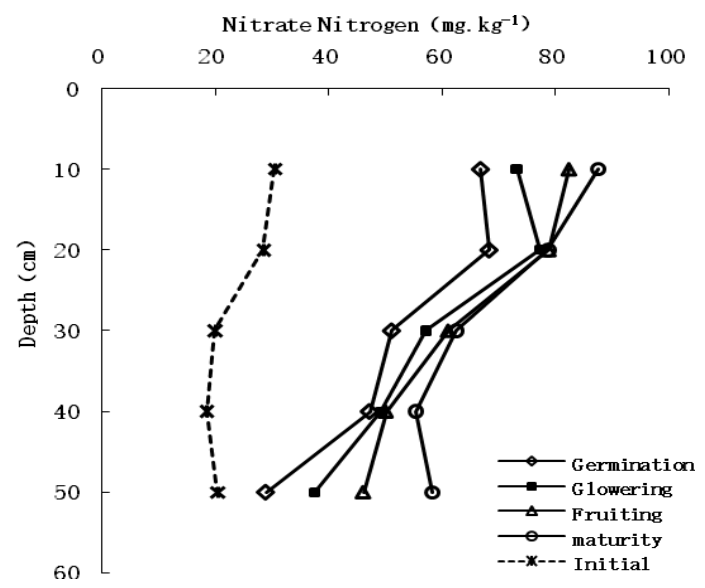

Figure 2 (b). Soil Nitrate Nitrogen Vertical Variation:3gL-1 Salt Water

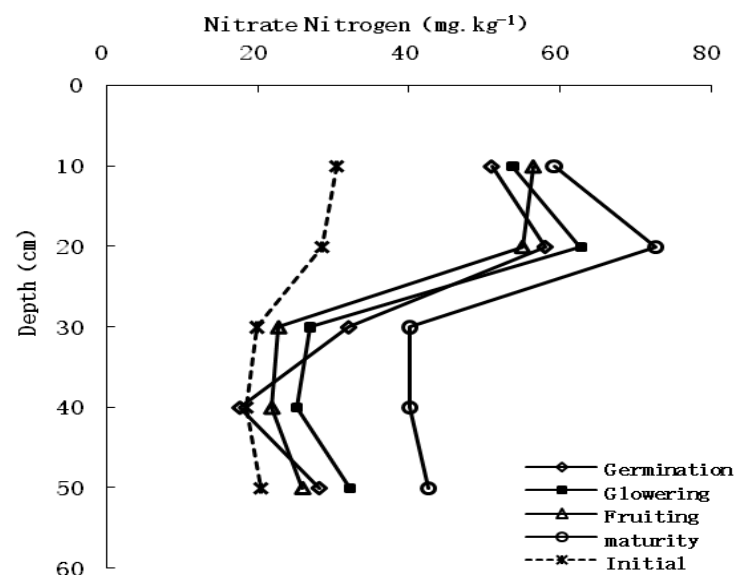

Figure 2 (c). Soil Nitrate Nitrogen Vertical Variation:4gL-1 Salt Water

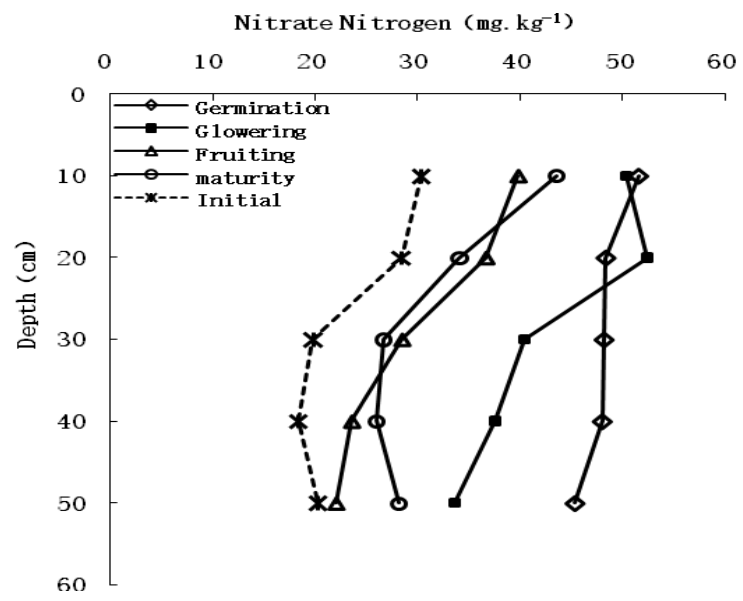

Figure 2 (d). Soil Nitrate Nitrogen Vertical Variation: Fresh Water 


\section{Discussion}

Soil microorganisms and community functional diversity were affected significantly by saline water irrigation, and $\mathrm{N}$ application at proper rates could maintain soil microbial community activity and diversity [22].Brackish water drip irrigation had a significant adverse effect on soil enzyme activities, which decreased soil microbial biomass, soil $\mathrm{CO} 2$ flux and soil organic matter decomposition, and subsequently deteriorated the soil biological characteristics in oasis farmland[23]. Long-term saline groundwater irrigation not only influences the chemical and physical characteristics of soils, such as biomass carbon, biomass nitrogen, organic matter and total nitrogen [24], but also bring direct influences to soil biological properties. Therefore, this research brings important implications for soils health and sustainability in arid agricultural zones.

Under different saline water salinity treatment conditions, from the emitter (or root) nearer place, the overall available nitrogen content the higher, the farther away from the emitter where the available nitrogen content be reduced, resulting in large part of the available nitrogen accumulated in the vicinity of the emitter. It would produce toxic effects for jujube roots, inhibiting jujube growth, in the production practice that should be noted [25]. When the degree of salinity of irrigation water was higher, the soil available nitrogen level would be higher, but the nitrogen utilization rate in jujube roots was relatively smaller, because of the increase of salt concentration in soil. After changing the local soil conditions, available nitrogen transformation process was inhibited. From this we can assume that, when the salinity across the threshold, in addition to blocked nitrogen into use in jujube tree roots, at the same time, would increase soil nitrogen and reduce nitrogen loss, this issue needed further discussion.

Yang Xiao and other studies have shown that after waste water irrigation, the majority of nutrients was absorbed by colloids and enriched in the topsoil[16-20], so the total soil nutrient content distribution trend with increasing soil depth decreases [26-27], Li Fayong's studies also have shown, $10 \mathrm{~cm}$ and $20 \mathrm{~cm}$ nitrate nitrogen content to be significantly higher than fresh water, indicating that saline water could improve surface-soil nitrate nitrogen [28], and Qian Juju's research showed that water quality conditions in different ,the soil surface N03-N peak changes as followed: water> dilute the sewage> recycling water> water. Huang Guanhua had got the similar conclusions. After saline water Irrigation, in jujube root zone of the soil nitrate content than the initial values were different levels of growth and decline, which was consistent with the study of equality Li Ping's, $40 \mathrm{~cm}$ and $50 \mathrm{~cm}$ jujube root zone soil nitrate nitrogen levels appeared to increase slightly, indicating that the role of fertilization increases and wastewater irrigation at the same time, which maked the soil NO3-N concentration increasing, with irrigation amount would cause soil $\mathrm{NO}_{3}-\mathrm{N}$ movement into deeper soil [29]. Our research demonstrated, after $3 \mathrm{~g} \cdot \mathrm{L}^{-1}$ and $4 \mathrm{~g} \cdot \mathrm{L}^{-1}$ saline water drip irrigation, soil nitrate nitrogen levels were significantly higher than freshwater in Jujube root zone.

\section{Conclusion}

After different salinity saline water irrigating, the soil available nitrogen gradually decreased trend from top to bottom in the whole soil, the highest values of soil available nitrogen content appeared in surface soil with depths of $10 \mathrm{~cm}$ and $20 \mathrm{~cm}$; the second value appeared in the depth of $40 \mathrm{~cm}$; and the minimum values appeared in depths of $30 \mathrm{~cm}$ and $50 \mathrm{~cm}$. 
Through analysis of soil available nitrogen variability obtained with saline water salinity increases, its coefficient of variation firstly increased, then reduced, that is fresh water $<4 \mathrm{~g} \cdot \mathrm{L}^{-}$ ${ }^{1}<2 \mathrm{~g} \cdot \mathrm{L}^{-1}<3 \mathrm{~g} \cdot \mathrm{L}^{-1}$ saline water treated soil available nitrogen variability in the maximum, indicating soil available nitrogen transformed and used that was instability in Jujube root zone, in the 2-3 $\mathrm{gL}^{-1}$ would appeared irrigation water salinity threshold point that impacted available nitrogen.

After different saline water salinity treatment, in different growth stages of the Jujube, $10 \mathrm{~cm}$ and $20 \mathrm{~cm}$ high nitrate nitrogen levels, $30 \mathrm{~cm}, 40 \mathrm{~cm}, 50 \mathrm{~cm}$ value was relatively small, $\mathrm{Li}$ Fayong and other studies had acquired the same results, indicating that saline water drip irrigation would be in favour of soil nitrate accumulation. By analyzing the variability of soil nitrate nitrogen, we obtained large variation coefficients under $2 \mathrm{~g} \cdot \mathrm{L}^{-1}$ and $4 \mathrm{~g} \cdot \mathrm{L}^{-1}$, which indicated that absorption and utilization of nitrate nitrogen was been unstable by the Jujube root systems. Relative to the initial value, soil nitrate nitrogen was effected by the order of saline water salinity that was $3 \mathrm{~g} \cdot \mathrm{L}^{-1}>4 \mathrm{~g} \cdot \mathrm{L}^{-1}>$ freshwater $>2 \mathrm{~g} \cdot \mathrm{L}^{-1}$. Therefore, when used the saline water to irrigate the Jujube, the $2 \mathrm{~g} \cdot \mathrm{L}^{-1}$ was been suitable.

\section{Acknowledgments}

The work of this paper is supported by National Natural Science Foundation of China (31060084, 41561088, 51169023),National Sci-Tech Support Plan China(2014BAC14B01) and open topics of Xinjiang Production and Construction Corps, including Research and Demonstration of High-quality and High Yield Technologies of Jujubes Based on Inflorescence Development Regulation.

\section{References}

[1] Y.Jiang and W.Hao, "The Characteristics of Meadow Brown Soil with Different Use Patterns of Nutrients in Soil Depth",Soil and Water Conservation, vol.20, (2006),pp.93-96.

[2] N.Li, H.Li, and F.Zhang, "The Relationship Between Microbial Ecological Characteristics and Soil Physical and Chemical Nature", Journal of Applied Ecology, vol.17, (2006), 285-290.

[3] C.Shi, and Q. L.Zhuang, "Soil Nitrogen Profile Distribution at Different Latitudes in Northeastern",Ecology, vol.26, (2007), pp.501-504.

[4] N.Fu, and Y.Hong, "Controlled-release Fertilizer and Urea Fertilizer's Effects on Soil Nitrogen Content in Tea and Tea Quality”,Northwest Agricultural University, vol.19, (2010), pp. 106- 109.

[5] H.Bai, B.Cui, and Z.Yang, "The Seasonal Variation Study of Marsh Soil Nitrogen Content in Xianghai”,Chinese Eco-agriculture Newspaper, vol.14, (2006), pp.115-117.

[6] H.Chang, "The Preliminary Analysis for Yulin Date Garden Soil Nitrogen along The Yellow River",Hubei Agricultural Sciences, vol.47, (2008), pp.895-896.

[7] S.Feng, S.Huan, "Field Trials on New Drip Irrigation of Cotton Fertilizer Coupling effects", China Agricultural University Newspaper, vol.3, (1998), pp.59-62.

[8] W.Xing, L.Wang, "Corn Fertilizer Coupling Effects in semiarid zones. Soil Moisture and Available Nitrogen Dynamic Distribution”,Soil, vol.35,( 2003), pp. 242-247.

[9] K.Steven, "Study about Waste Water Irrigation's Effects on Nitrogen Contents of Soil and Plant Grass", Journal of Agricultural Engineering, vol.18, (2005), pp. 22-25.

[10] A.Hayes, and M. Pepper, "Irrigation of turfgrass with secondary sewage effluent". Soil and Leachate Water Quality”. Agron J, vol.82, (1990), pp. 939-943.

[11] C.Smith, P.Chalk, and C.Noble,1993. "Nitrogen fixation in a white clover-grass pasture irrigated with saline groundwater”, Irrig Sci, vol.13, (1993), pp.189-194. 
[12] Y.Li and Y.Li, "Recycled Water Chlorination's Effects on the Drip Irrigation System and Tomato Yield and Nitrogen Uptake”. Journal of Agricultural Engineering, vol.26, (2011),pp.18-23.

[13] F.Li, L.Wang, and X.Yang, "Researches on Nitrogen Distribution Characteristics under Brackish Water Dripping in Root Zone". Tarim University, vol.22,(2010),pp. 12-18.

[14] N.Li, X.Wang, and X.Li, "Effect of Different Ferrilization Modes and Drip Irrigation Quotas with Saline Water on Enzyme Activities at Jujube Root Zone".Journal of Irrigation and Drainage, vol.32, (2013),pp.8083.

[15] C.Wang, N.Li, and X.Wang, "Vertical Distribution of Soil Organic Carbon Content in Rhizosphere of Jujube at Its Different Growth Stages under Drip Irrigation with Salty Water" .Arid Zone Research, vol.29, (2012),pp.883-889.

[16] J.Zhang J. L., "Effect of Farmland Irrigation and Drainage on Soil Water-salt Transport of Jujube Root Zone in Arid Zone".Journal of Soil and Water Conservation, vol.28, (2014), pp.278-283.

[17] K.Rothlisberge, J. Foster, "Soil carbon and nitrogen dynamics as affected by lipid-extractedalgae application”. Geoderma, vol.262, (2016), pp. 140-146.

[18] H.Wang, Z.Guo, "Impact of tillage practices on nitrogen accumulation and translocationin wheat and soil nitrate-nitrogen leaching in drylands".Soil \& Tillage Research, vol.153, (2015),pp.20-27.

[19] X.Wang, Y.Su, "Water use and soil nitrate nitrogen changes under supplementalirrigation with nitrogen application rate in wheat field". Field Crops Research, vol.183,(2015),pp.117-125.

[20] Z.Wang, "Effect of ammonium and nitrate nitrogen fertilizers on wheat yield inrelation to accumulated nitrate at different depths of soil in drylands of China".Field Crops Research, vol.183, ( 2015), pp.211-224.

[21] S.Bao, "Soil Agrochemicallization Analysis", China Agriculture Press, Beijing, (2000).

[22] W.Min, "Soil microbial activity and community functional diversity in cotton field under long-term drip irrigation with saline water".Chinese Journal of Ecology, vol.33, (2014), pp.2950-2958.

[23] Q.Zhang, "Effects of brackish water irrigation on soil enzyme activity,soil CO2 flux and organic matter decomposition”. Chinese Journal of Applied Ecology, vol.26, (2015), pp.2743-2750.

[24] G.Wang, "Effects of long-term irrigation with brackish groundwater on soil microbial biomass in cotton field in arid oasis", Transactions of the CSAE, vol.25, (2009), pp.44-48.

[25] H.Hou, "Research on Nitrogen Transformation Laws in Greenhouse Dripping Conditions", China Agricultural Science and Technology News, vol.6, (2002), pp.56-57.

[26] X.Yang, "Research on Migration and Transformation of Sewage Irrigation Soil Nutrient", Xinjiang University, Xinjiang. (2006).

[27] J.Qian, "Studies on Crop growth and Nitrogen Transport Pilot under the Conditions of Sewage Irrigation",Chinese Academy of Agricultural Sciences, Beijing.(2006).

[28] P.Li, H.Pang, "Test on Nitrogen Migration in Different Irrigation Water Diving Depth",Irrigation and Drainage, vol.26, (2007),pp.1-5.

[29] G.Lu, "The Preliminary Study about Nitrogen Migration and Transformation Situations under Conditions of Effluent Irrigation and Nitrogen Fertilizer", China Agricultural University, Beijing, (2002). 
International Journal of Security and Its Applications Vol. 10, No. 2 (2016) 